\title{
Analysis of pharmacists' knowledge and attitude in the pharmaceutical industry of halal certification and their readiness to produce halal medicine
}

\author{
Abdul Rahem ${ }^{1}$, Mustofa Helmi Effendi ${ }^{2}$, Hayyun Durrotul Faridah ${ }^{3}$ \\ ${ }^{1}$ Faculty of Pharmacy, Universitas Airlangga, Surabaya, Indonesia \\ ${ }^{2}$ Faculty of Veterinary Medicine, Universitas Airlangga, Surabaya, Indonesia \\ ${ }^{3}$ Faculty of Science and Technology, Universitas Airlangga, Surabaya, Indonesia
}

Keywords
Attitude
Halal
Medicine
Readiness
Correspondence
Abdul Rahem
Faculty of Pharmacy
Universitas Airlangga Indonesia
Level 4
Nanizar Zaman Joenoes Building
Campus C Universitas Airlangga
Jl. Mulyorejo Surabaya
Indonesia
abdulrahem@ff.unair.ac.id

\section{Introduction}

The world's need for halal products, including food, cosmetics, pharmaceuticals, services, and other products, will continue to increase along with the increase of the global Muslim population (Yusuf, Shukri \& Yajid, 2016). Even today, the trend of halal products is not only developing in countries where the population is predominantly Muslim (Saha, Rifat, \& Shimanto, 2019). Non-Muslim countries such as Japan and South Korea are becoming increasingly interested in halal products (Yusof \& Shutto, 2014; Satriana \& Faridah, 2018). In those countries, halal is considered to be the benchmark for guaranteeing food safety and quality (Saha et al., 2019). In the last five years, the general public awareness of halal products has begun to increase (Saha et al., 2019). There is also an increasing awareness among Muslims to avoid consuming all items containing non-halal ingredients, including medicinal products (Sadeeqa \& Sarriff, 2014).

Pharmaceutical products rarely get a halal certificate, and there are only a few medicines with halal certificates (Aziz et al., 2014). This makes the halal status of certain products unknown. The absence of detailed information about additional ingredients in the drug brochure is one of the factors that cause the halal drug status to be unknown (Aziz et al., 2014). Medicinal products consist of a combination of active ingredients and excipients. The active ingredient is the 
main ingredient used to treat disease, and there is usually only one of these in a product. Meanwhile, the excipient ingredients are additives, and there are usually more than one of these in a product. Excipients added to the active ingredient are used to provide good physical qualities, such as taking tablet form or acting as a diluent, flavouring agent, dye, binder, or preservative (Regenstein \& Chaudry, 2003; Aziz et al., 2014). The active ingredient and the excipients must both come from halal ingredients and be processed without any additional non-halal material sources (Khan et al., 2013) because the halalness of medicinal products is determined by both of them.

Halal medicine can be defined as medicine that comes from halal materials, which can be sourced from plants, animals, or organic/non-organic substances starting from the process of preparation, production and extraction according to the Islam rules. In addition, it must be ensured that the drug is free from additives that are not halal (Khan \& Shaharuddin, 2015). Halal certification for all medicinal products is needed in order to confirm the status of these products. The halal status will reduce the confusion and doubt of consumers to consume the product because it is in clear accordance with the teaching of their religion (Garg \& Joshi, 2018).

The suspicion regarding the illegality of drugs that have not included a halal label is based on the fact that many of the additives come from pork. For example, pork gelatine is often used as a capsule shell. Gelatine is a component commonly used in food, cosmetics and pharmaceutical products because of its gelling properties (Rohman et al., 2020). The consumption of food products from pork sources is strictly prohibited in Islam. Gelatine and collagen are important ingredients in products and become critical points in determining halalness. These ingredients come from cows, but a few also come from pigs (Yuswan et al., 2021). In addition, gelatine and collagen are widely used in various applications, such as in the food and pharmaceutical industries (Shabani et al., 2015). Currently, Muslim scientists are still looking for alternative ingredients to use in halal medicine (Saha et al., 2019). For instance, gelatine can be replaced with polysaccharides that are guaranteed to be halal (Faridah, 2019). Some polymers made from polysaccharides can be used as substitutes for gelatine materials; these include carrageenan, xanthan gum, maltodextrin, alginate, chitosan, gellan gum, and guar gum (Jana et al., 2011). In addition, the halalness of pharmaceutical products is also determined by the process of production, packaging, storage, distribution and service. Besides having to be halal, everything that is consumed must also be safe, which means it cannot be harmful and must have good quality. This is commonly called "Halalan Toyyiban" in Islamic law (Aziz \& Sulaiman, 2014).

The halalness of medicines is also determined by pharmacists being competent professionals in terms of pharmaceutical products. The role of pharmacists, both those who practice in the pharmaceutical industry and those who practice in the service, provide big hope to the community that they will ensure the availability of halal medicines. For pharmacists who practice in the pharmaceutical industry, select and prepare medicinal raw materials, carry out the production process, ensure that the products are of quality and ensure that the drugs produced meet the requirements according to applicable standards, including their halalness. Apart from halal medicines, it is important to initiate pharmacists from educational institutions in order to have sufficient human resources. However, until today the pharmacy curriculum regarding halal and haram medicines is still rarely discussed (Aziz et al., 2014).

Pharmacists must have knowledge about halal and haram matters (Sarriff \& Razzaq, 2013) so that those who practice in the service are able to explain to patients the availability of halal treatment options. These efforts can increase patient satisfaction and the trust that they have for their chosen medical services (Khan \& Shaharuddin, 2015). Consulting services to find out halal information about the pharmaceutical preparations of products is part of a must-have skill for pharmacists (Syahrir, Rahem \& Prayoga, 2019). Therefore, the aim of this study is to analyse the knowledge and attitude of pharmacists towards halal certification and their readiness to produce halal medicine.

\section{Methods \\ Study design}

This research was conducted in November 2018 in East Java using primary data and a questionnaire that had previously been tested for validity and reliability. The questionnaire given included several questions with three main topics: knowledge, attitudes and acceptance of halal drug certification. The research subjects were 206 respondents who were pharmacists working in the pharmaceutical industry in East Java. An ethics approval was not deemed necessary as the survey population did not include any-risk groups, and anonymity was assured to all participants. In addition, signed informed consent was obtained from all participants prior to data collection. 
Population, sample, and sampling technique

The research population were pharmacists who attended a professional training event by the East Java Industrial Pharmacist Association in November 2018. The research sample was part of the population with the following inclusion criteria: pharmacists who were Indonesian citizens, willing to become respondents by filling out informed consent and who have worked in the industry with a minimum of five years of work experience. The sampling technique carried out was random sampling. The sample size was 206 pharmacists, and the sample size (n) was calculated using the simple random sampling formula with notation $\mathrm{N}$ (total population size), $\mathrm{P}$ (population proportion), and $\mathrm{d}$ (degree of error) as shown below (Ogston et al., 1991):

$$
\operatorname{Vâr}(\hat{P})=\frac{P(1-P)}{n} \times \frac{N-n}{N-1} .
$$

$Z=1.96 ; P=0.5 ; d=0.05 ; N=440$ pharmacists; thus, $n$ $=205.34=206$ pharmacists

\section{Research variables}

The research variables consisted of the independent and dependent variables. The independent variables were the knowledge and attitude of the pharmacists in the pharmaceutical industry in regards to halal certification. The dependent variable was the readiness of pharmacists in the pharmaceutical industry to produce halal drugs. The variable data were in the form of the respondents' answers to the questionnaire given to them.

\section{Data analysis}

The data from the answers to the questionnaire were tested for normality first using the one-sample Kolmogorov-Smirnov test. If it showed that the data were normally distributed, then the parametric test used for the correlation test was the Pearson test. If the data were not normally distributed, then the nonparametric test that was used for the correlation test was Spearman's rank test. After analysing the normality of the data, it turned out that the data were not normally distributed. Furthermore, to determine the relationship between the pharmacists' knowledge and attitude towards halal certification as well as their readiness to produce halal medicines, an analysis was carried out using the Spearman's rank correlation test. The Mann-Whitney test was also used to determine the differences in knowledge, attitudes, and readiness of respondents regarding halal certification and production of halal drugs while age, length of work, and ownership were analysed using the Kruskal-Wallis test. $p<0.05$ was considered statistically significant.

\section{Results}

\section{Respondents characteristics}

Characteristics of respondents were grouped based on the sex, age, length of practice, and ownership of the pharmaceutical industry in which they work. $69.9 \%$ of respondents in this study were women; this statistic is presented in Table I.

Table I: Respondents characteristics

\begin{tabular}{lcc}
\hline Category & $\begin{array}{c}\text { Frequency } \\
\text { (n: 206) }\end{array}$ & Percentage (\%) \\
\hline Gender & 144 & 69.9 \\
Female & 62 & 30.1 \\
Male & & \\
\hline Age (years) & 135 & 65.5 \\
$\leq 35$ & 47 & 22.8 \\
36 - 45 & 20 & 9.7 \\
46 - 55 & 4 & 2 \\
$\geq 56$ & 173 & \\
\hline Duration of practice (years) & 17 & 84.0 \\
$\leq 10$ & 10 & 8.3 \\
11-20 & 6 & 4.9 \\
$21-30$ & 21 & 2.9 \\
$\geq 31$ & 154 & \\
\hline Pharmaceutical industry ownership & 11.7 \\
Foreign investment (PMA) & 24 & 74.8 \\
$\begin{array}{l}\text { Domestic investment } \\
\text { (PMDN) }\end{array}$ & 7.4 \\
State-owned enterprises & & \\
(BUMN) & & \\
Individuals & & \\
\hline & & \\
\hline
\end{tabular}

In this study, the majority of the respondents (65.5\%) were 35 years old or less; this can be seen in Table I. There were $2 \%$ of respondents aged 56 years old or more. The majority of respondents (84\%) had ten years or less as practice as a pharmacist in the pharmaceutical industry, and $2.9 \%$ had 31 years or more of work experience.

\section{Respondents' knowledge of the halal drug certification}

Respondents' knowledge about halal drug certification was divided into three categories: low, medium, and 
high. Data on knowledge in Table II showed that the majority of respondents (48\%) had low-category knowledge in regards to halal drug certification.

Table II: Respondent data

\begin{tabular}{lcc}
\hline Category & $\begin{array}{c}\text { Frequency } \\
\text { (n: 206) }\end{array}$ & Percentage (\%) \\
\hline Respondents' knowledge & 100 & 48.5 \\
Low & 89 & 43.2 \\
Medium & 17 & 8.3 \\
High & 19 & 9.22 \\
\hline Attitude of respondents & 107 & 51.94 \\
Disagree & 80 & 38.84 \\
Agree & & \\
Strongly agree & 10 & 4.85 \\
\hline Respondents' readiness & 121 & 58.74 \\
Not ready & 75 & 36.41 \\
Ready & & \\
Very prepared & & \\
\hline
\end{tabular}

The attitude of the respondents towards the halal drug certification

Based on the questionnaire given to the respondents, it was found that only $9.22 \%$ of respondents disagreed with the halal certification of drugs while the remaining 90.78\% agreed. As much as $51.94 \%$ and $38.84 \%$ stated that they strongly agreed, as shown in Table II.

\section{Readiness of respondents for halal drug certification}

Only $4.85 \%$ of respondents stated that they were not ready to produce halal-certified drugs, as seen in Table II. The percentages that stated that they were ready and very ready were $58.74 \%$ and $36.41 \%$, respectively. If combined, the ready and very ready respondents added up to $95.15 \%$. This is a consequence of the prevailing laws and regulations, in which all industries have to prepare themselves to carry out certification and produce halal drugs. The author did not conduct an audit on each pharmaceutical industry but rather collected data through questionnaire answers given to respondents.

The data normality test can be seen in Table III.
Table III: Data normality test

\begin{tabular}{|c|c|c|c|}
\hline Variable & $\begin{array}{l}\text { Statistical } \\
\text { test }\end{array}$ & $p$-value & Description \\
\hline $\begin{array}{l}\text { Age of } \\
\text { respondents }\end{array}$ & $\begin{array}{l}\text { Kolmogorov- } \\
\text { Smirnov }\end{array}$ & 0.0001 & $\begin{array}{l}\text { Data } \\
\text { distribution is } \\
\text { not normal }\end{array}$ \\
\hline $\begin{array}{l}\text { Duration of } \\
\text { practice }\end{array}$ & $\begin{array}{l}\text { Kolmogorov- } \\
\text { Smirnov }\end{array}$ & 0.0001 & $\begin{array}{l}\text { Data } \\
\text { distribution is } \\
\text { not normal }\end{array}$ \\
\hline Knowledge & $\begin{array}{l}\text { Kolmogorov- } \\
\text { Smirnov }\end{array}$ & 0.0001 & $\begin{array}{l}\text { Data } \\
\text { distribution is } \\
\text { not normal }\end{array}$ \\
\hline Attitude & $\begin{array}{l}\text { Kolmogorov- } \\
\text { Smirnov }\end{array}$ & 0.0001 & $\begin{array}{l}\text { Data } \\
\text { distribution is } \\
\text { not normal }\end{array}$ \\
\hline Readiness & $\begin{array}{l}\text { Kolmogorov- } \\
\text { Smirnov }\end{array}$ & 0.0001 & $\begin{array}{l}\text { Data } \\
\text { distribution is } \\
\text { not normal }\end{array}$ \\
\hline
\end{tabular}

Based on the statistical analysis shown in Table IV, there were no differences in knowledge, attitudes, and readiness related to certification and production of halal drugs between both genders. Likewise, there were no significant differences as a result of the variables of age and length of work, with each p-value being more than 0.05 . This meant that gender, age, and length of work did not affect the knowledge, attitudes, and readiness of respondents towards the certification and production of halal drugs.

\section{Discussion}

The results of this study were in accordance with the characteristics of pharmacists in Indonesia, as seen in other research conducted by Satibi and the authors (2018) in different practice settings. For example, at the Health Center (Puskesmas) in 2018, the majority of pharmacists were women (72.2\%) (Satibi et al., 2018). Although jobs in the pharmaceutical industry are harder than in services, especially for female pharmacists, there are still more women who are interested in the industry because there are more female pharmacists in the East Java region. There were $76 \%$ of pharmacists in the East Java region were women based on data from the Indonesian Pharmacists Association of East Java (Syahrir et al., 2019). Syahrir's research that was carried out in various pharmaceutical practice settings also shows that $86 \%$ of respondents are female (Syahrir et al., 2019). 
Table IV: Data analysis

\begin{tabular}{llccc}
\hline Characteristics & Categories & Knowledge & Attitude & Readiness \\
M \pm SD & M \pm SD & $25.02 \pm 2.63$ \\
\hline Gender & Female & $17.55 \pm 5.49$ & $25.02 \pm 2.71$ & $24.32 \pm 3.64$ \\
& Male & $18.74 \pm 5.19$ & $24.03 \pm 3.30$ & 0.052 \\
& Mann-Whitney $(p)$ & 0.289 & 0.068 & $24.60 \pm 3.11$ \\
\hline Age & $\leq 35$ & $17.58 \pm 5.47$ & $24.95 \pm 3,03$ & $25.34 \pm 2.61$ \\
& $36-45$ & $18.47 \pm 5.73$ & $24.83 \pm 2.63$ & $25.30 \pm 3.03$ \\
& $46-55$ & $18.20 \pm 4.19$ & $24.70 \pm 3.03$ & $23.00 \pm 1.00$ \\
& $\geq 56$ & $21.00 \pm 7.00$ & $23.33 \pm 3.06$ & 0.229 \\
Kuration of Practice & $\leq 10$ & 0.566 & 0.084 & $24.71 \pm 3.00$ \\
& $11-20$ & $17.64 \pm 5.42$ & $24.87 \pm 2.99$ & $25.94 \pm 2.49$ \\
& $21-30$ & $19.76 \pm 6.18$ & $25.47 \pm 1.94$ & $25.50 \pm 3.81$ \\
& $\geq 31$ & $18.20 \pm 3.61$ & $25.10 \pm 2.73$ & $23.75 \pm 0.50$ \\
\hline Knowledge & Kruskal-Wallis $(p)$ & $17.50 \pm 4.04$ & $23.00 \pm 3.46$ & 0.196 \\
\hline
\end{tabular}

The practice conditions are related to the existing policies in Indonesia, namely the minimum requirement of three pharmacists in the pharmaceutical industry starting from the existence of Government Regulation number 51 of 2009 concerning pharmaceutical work (Syahrir et al., 2019). The regulation states that the person in charge of production, quality control, and quality assurance must be a pharmacist. This regulation came into effect on the $1^{\text {st }}$ of September 2009, which was approximately ten years before the conduction of this research. Another thing is the recruitment of employees in the pharmaceutical industry in Indonesia usually has a maximum age limit of 35 years old, so it is natural that the majority of pharmacists working in the pharmaceutical industry are currently aged 35 or less. This research is the same as that conducted by Cambrey Nguyen in 2020, which stated that the majority of pharmacists $(70 \%)$ who work in the industry are aged 35 or less old (Nguyen, 2020). This shows that most of the respondents were relatively young and at a very productive period. Based on the author's experience, most pharmacists that work in the industry are relatively young. After having experience in the industry and entering a more elderly age as well as having sufficient capital, people usually work in easier places such as in pharmacies or as lecturers at universities.

The results show that the respondents are mostly new pharmacists who started working in the pharmaceutical industry after the issuance of government regulation number 51 in 2009. Based on the ownership of the pharmaceutical industry, $74.8 \%$ of respondents' place of work was mainly in the domestic capital owner industry (PMDN). Meanwhile, the remaining $25.2 \%$ were spread across the pharmaceutical industry, foreign investment (PMA), state-owned enterprises (BUMN), and individuals.

The findings show that the respondents lacked knowledge regarding the concept of halal and halal drug certifications. This result is in accordance with what was conveyed by Eddy Yusuf and the authors (2016), where they stated that the biggest current challenge was the pharmacists' lack of understanding in the industry regarding the concept of halalness (Yusuf et al., 2016). This is understandable because the existing pharmacy education curriculum has not included the concept of halalness as a part of the learning. In addition, training related to the halal 
industry, especially in the pharmaceutical industry, has not been implemented much, unlike training related to International Organization for Standardization (ISO) management and good drug manufacturing methods that have been carried out by many training agencies and government institutions. Even professional organisations such as the Indonesian Pharmacists Association often hold training to improve pharmacists' competence in the industry, especially regarding how to make good medicines.

For respondents who had knowledge that was categorised high and very high in regards to halal, the possibility was that they were pharmacists who had already had a foundation of good religious understanding because of their religious family background or their activeness in Islamic activities. In this study, there were no data to reveal this. In regards to this, it is very necessary to adjust the pharmacist education curriculum to include material related to the halal concept and encourage training institutions or competent institutions such as Badan Penyelenggara Jaminan Produk Halal (BPJPH) to carry out training on an ongoing basis. It has to be implemented because training is needed in order to improve the competency of the resources needed by the industry, as stated by Norazmi \& Lim (2015).

There were several reasons for the halal certification agreement, including the fact that the regulation had been established in 2014 and had become effective starting from the $17^{\text {th }}$ of October 2019. Therefore, it has not been possible not to follow the applicable regulations in Indonesia while still producing drugs in the country. Another reason is the market has started to undergo an increase in demand for halal drugs from various hospitals, especially in areas with most populations were Muslim and in hospitals that have been declared as religious hospitals. With so much request for halal drugs, the pharmaceutical industry must adjust to these conditions by producing halal drugs; otherwise, it will die by itself because the products are not needed by customers. This research is in line with that conducted by Syahrir and the authors (2019), which states that the acceptance/attitude of pharmacists regarding halal drugs strongly agrees with the $89 \%$ index (Syahrir et al., 2019).

Analysis of the relationship between knowledge and the readiness of respondents regarding certification and production of halal drugs obtained a value of $p=$ 0.566 or $p>0.05$, which means that there was no significant relationship between knowledge and readiness. The analysis of the relationship between attitude and readiness obtains values of $p=0.0001$ and $r=0.602$. This shows that there is a significant relationship between the respondents' attitude and readiness in regards to the certification and production of halal drugs. The relationship is a strong value of $r=$ 0.602 . From all these statistical analyses, it can be explained that the readiness to produce halal drugs is only influenced by the positive attitude of the respondents, while other factors in this study have no effect.

\section{Conclusion}

From the research conducted above, it can be concluded that pharmacists' knowledge regarding halal certification on drugs is still lacking. The attitude of the respondents towards the halal certification of drugs showed that $51.94 \%$ of respondents agreed with the halal certification of drugs and that $58.74 \%$ of respondents were ready to produce drugs with halal certification.

\section{Conflict of interest}

The authors state that there were no conflicts of interest in this study and the article.

\section{Authors' declaration}

The authors hereby state that the data and all contents presented in this article are original research results from the authors. Any liability for claims relating to the content of this article will be borne by the authors.

\section{Acknowledgements}

The authors would like to thank the chairman of the Indonesian Pharmacists Association in East Java, and the head of the East Java Industrial Pharmacists Association for granting permission for this research to be carried out.

\section{References}

Aziz, N. A., Majdina, H., Hassan, Y., \& Hanum, H. (2014). Assessment of the Halal Status of Respiratory Pharmaceutical Products in a Hospital. Procedia - Social and Behavioral Sciences, 121(September 2012), 158165. https://doi.org/10.1016/j.sbspro.2014.01.1117

Aziz, N. A., Ibrahim, I., \& Abdul, N. (2014). The Need for Legal Intervention within the Halal Pharmaceutical Industry. Procedia - Social and Behavioral Sciences, 121(September 2012), 124132. https://doi.org/10.1016/j.sbspro.2014.01.1114

Aziz, N. A., \& Sulaiman, S. S. (2014). Role of the Local Authority in Issuing License for Halal Certified Premise in the City of Shah Alam. Procedia - Social and Behavioral Sciences, 121 (September 2012), 133-143. https://doi.org/10.1016/j.sbspro.2014.01.1115 
Garg, P., Joshi, R. (2018). Purchase intention of " Halal " brands in India: the mediating e ff ect of attitude. https://doi.org/10.1108/JIMA-11-2017-0125

Khan, T., \& Shaharuddin, S. (2015). Need for contents on halal medicines in pharmacy and medicine curriculum. Archives of Pharmacy Practice, 6(2), 38. https://doi.org/10.4103/2045080x.155512

Khan, T., Shaharuddin, S., Satriana, E. D. (2013). Need for contents on halal medicines in pharmacy and medicine curriculum. Journal of Halal Product and Research, 1(1), 1521. https://doi.org/10.20473/jhpr.vol.1-issue.2.32-43

Nguyen, C. (2020). The role of a pharmacist as a medical information specialist in the pharmaceutical industry. Currents in Pharmacy Teaching and Learning, 12(2), 127-131. https://doi.org/10.1016/j.cptl.2019.11.005

Norazmi, M. N., \& Lim, L. S. (2015). Halal pharmaceutical industry : opportunities and challenges. Trends in Pharmacological Sciences, 36(8), 496-497. https://doi.org/10.1016/j.tips.2015.06.006

Ogston, S. A., Lemeshow, S., Hosmer, D. W., Klar, J., \& Lwanga, S. K. (1991). Adequacy of Sample Size in Health Studies. Biometrics, 47(1), 347. https://doi.org/10.2307/2532527

Regenstein JM, Chaudry MM, Regenstein, C. E. (2003). The Kosher And Halal Food Laws. Compr Rev Food Sci Food Saf, (2), 111-127.

Rohman, A., Windarsih, A., Erwanto, Y., \& Zakaria, Z. (2020). Review on analytical methods for analysis of porcine gelatine in food and pharmaceutical products for halal authentication. Trends in Food Science and Technology, 101(January), 122132. https://doi.org/10.1016/j.tifs.2020.05.008

Sadeeqa, S., \& Sarriff, A. (2014). Comparing KAP regarding Halal pharmaceuticals among general practitioners and hospital doctors, 4(10), 92-96. https://doi.org/10.7324/JAPS.2014.40117

Saha, T., Rifat, T., \& Shimanto, S. (2019). Prospects of Halal Pharmaceuticals. Asian Journal of Ethnopharmacology and Medicinal Foods, 5(2), 17-23.

Sarriff, A., \& Abdul Razzaq, H. A. (2013). Exploring the halal status of cardiovascular, endocrine, and respiratory group of medications. Malaysian Journal of Medical Sciences, 20(1), 69-74.

Satibi, S., Daulay, E. H., Oviani, G. A., Erlianti, K., Fudholi, A., \& Puspandari, D. A. (2018). Performance Analysis of Pharmacist and Influencing Factors in the Era of National Healt Insurance at Puskesmas. Journal of Management and Pharmacy Practice, 8(1), 32. https://doi.org/10.22146/jmpf.34441

Satriana, E. D., \& Faridah, H. D. (2018). Halal Tourism: Development, Chance and Challenge. Journal of Halal Product and Research, 1(2), 32. https://doi.org/10.20473/jhpr.vol.1-issue.2.32-43

Shabani, H., Mehdizadeh, M., Mohammad, S., \& Ansari, E. (2015). Halal authenticity of gelatin using species-specific PCR. Food Chemistry, 184, 203-206. https://doi.org/10.1016/j.foodchem.2015.02.140

Syahrir, A., Rahem, A., \& Prayoga, A. (2019). Pharmacist Behavior of Halal Labelization on Pharmaceutical Product. Journal of Halal Product and Research, 2(1), 25 - 32. https://doi.org/10.20473/jhpr.vol.2-issue.1.25-32

Yusof, S. M., \& Shutto, N. (2014). The Development of Halal Food Market in Japan: An Exploratory Study. Procedia - Social and Behavioral Sciences, 121(September 2012), 253-261. https://doi.org/10.1016/j.sbspro.2014.01.1126
Yusuf, E., Shukri, M., \& Yajid, A. (2016). Halal pharmaceuticals and cosmeceuticals from the perspective of higher education. Asian Journal of Pharmaceutical Sciences, 11(1), 18-19. https://doi.org/10.1016/j.ajps.2015.10.013

Yuswan, M. H., Nurul, N. H., Mohamad, H., Keso, S., Mohamad, N. A., Tengku, T. S., Mustafa, S. (2021). Hydroxyproline determination for initial detection of halal-critical food ingredients (gelatin and collagen). Food Chemistry, 337(April 2020). https://doi.org/10.1016/j.foodchem.2020.127762 